\title{
The Characteristics of Purun Tikus Particle Board Cement Board
}

\author{
Henry Wardhana ${ }^{1}$, Ninis Hadi Haryanti ${ }^{2}$ \\ ${ }^{I}$ FTeknik, Lambung Mangkurat University (ULM), South Kalimantan. Indonesia \\ ${ }^{2}$ FMIPA, Lambung Mangkurat University (ULM), South Kalimantan. Indonesia
}

\begin{abstract}
Nowadays, the use and utilization of natural fibers material continue to grow and highly demanded in the industrial world. There are various types of fiber plant thrive in Indonesia, such as kenaf (Hibiscus canabinus), blady grass (Imperata cylindrical), and Purun Tikus (Eleocharis dulcis). The existence of Purun Tikus still not used optimally. This study aims to determine the characteristics, the accurate composition of the mixed materials and the impact of Purun Tikus particle as materials for cement board. The results showed all Purun Tikus particle with a composition of $50 \mathrm{~g}+$ PPC $575 \mathrm{~g}$, $75 \mathrm{~g}+$ PPC $550 \mathrm{~g}$ and $100 \mathrm{~g}+$ PPC $525 \mathrm{~g}$ has met the requirements of SNI 03-2104-1991 on water content, density, thickness swelling, MoE. Not all the Purun Tikus particle meets the MoR in SNI 03-2104-1996 requirement. The lowest water level in the composition is at $50 \mathrm{~g}$ Purun Tikus particle without reinforcement while the highest at $100 \mathrm{~g}$ Purun Tikus particle with parallel reinforcement. The lowest density in the composition is at $75 \mathrm{~g}$ Purun Tikus particle with parallel reinforcement, while the highest at $75 \mathrm{~g}$ Purun Tikus particle without reinforcement. The lowest thickness swelling in the composition is at $100 \mathrm{~g}$ Purun Tikus particle without reinforcement, while the highest at $100 \mathrm{~g}$ Purun Tikus particle with parallel reinforcement. The lowest MoE in the composition of $100 \mathrm{~g}$ Purun Tikus particle without reinforcement, while the highest in $75 \mathrm{~g}$ Purun Tikus particle without reinforcement. The lowest MoR in the composition of $50 \mathrm{~g}$ Purun Tikus without reinforcement, while the highest in $75 \mathrm{~g}$ Purun Tikus particle with parallel reinforcement. The composition of Purun Tikus particle $75 \mathrm{~g}+$ PPC $550 \mathrm{~g}$ will be selected, because it has the highest value of the MoE.The composition of Purun Tikus particle $(50 \mathrm{~g}, 75 \mathrm{~g}, 100 \mathrm{~g})$ have a significant effect on the water content and the thickness swelling. The composition of Purun Tikus particle $(50 \mathrm{~g}, 75 \mathrm{~g}, 100$ g) have no significant effect on the density, the MoE and the MoR.
\end{abstract}

Keywords: purun tikus, cement board

\section{Introduction.}

Nowadays, the use and utilization of natural fibers material continue to grow and highly demanded in the industrial world. This is due to the natural fibers have a lower density, biodegradable, easily recycled, the production requires low energy, have a good mechanical properties and can be renewed because it comes from nature (Wang et all, 2003).

Indonesia has a wide biodiversity that provide a great opportunity to explore the use of natural fiber materials. The types of natural fibers such as ramie fiber, coconut fiber, water hyacinth fiber, palm fiber started to be used as a reinforcement source for material. There are various types of fiber plant thrive in Indonesia, such as kenaf (Hibiscus canabinus), blady grass (Imperata cylindrical), and Purun Tikus (Eleocharis dulcis).

Purun Tikus is a wild plant that lead as weeds in an open location. The Purun Tikus can be described as having a specific acid sulfate soil, because it is resistant to high acidity ( $\mathrm{pH} 2.5-3.5$ ). Therefore, this plant can be used as a vegetation indicator for acid sulfate soils (Steenis, 2006)

In terms of availability of natural fibers' raw materials, in the province of South Borneo has an abundant of waterchestnut's raw materials (Rahadi, 2007). Department of Industry, Trade and Investment (Disperindag and PM) Barito Kuala data in 2006 the distribution of sedge grass species reach $\pm 713 \mathrm{Ha}$, including $\pm 641 \mathrm{Ha}$ gray sedge plants and \pm 73 Ha waterchestnut. The existence of these Purun Tikus still not used optimally.

Purun Tikus is believed as one of the plants that contain a relative high fiber content, it is expected to be utilized for the development of construction materials.

Cement board is a panel product made by using raw material particles of lignisellulosa material and Portland cement as a binder. Comparison between the particles and cement in the manufacture process of cement board particle was 1.00: 2.75. The board has some advantages, such as moisture resistant, heat retardant, fungicide, and insecticide (Suhasman 2012).

The utilization of lightweight materials such as Purun Tikus is expected to reduce the weight, in addition the Purun Tikus are useful for improving the flexural strength in order to reduce the deflection due to loading, another advantage is being easy to obtain and growing wild in the swamp. Some advantages of Purun Tikus fiber believed to be used as a construction material therefore the research needs to be done. 


\section{Materials and Methods}

Materials and tools used in the manufacture process of cement board are based on the applicable ISO standards. The materials used are waterchestnut, cement and water. Purun Tikus is cut into particles with a maximum length of $3 \mathrm{~cm}$. The used cement is Pozolan Portland Cement (PPC) from 3 Roda Indocement, whereas the water used comes from Water Company.

The tool used is Universal Testing Machine (UTM) Gotech brand GT-7001-LC 10 model, the hydraulic cold press machine shown in the figure 3.2 , the mold $25 \mathrm{~cm}$ x $25 \mathrm{~cm}$ x $1 \mathrm{~cm}$, scales, oven and cutter and stirrer area.

This study is a continuation of previous studies. The test results of Purun Tikus characteristics reviewed from the chemical, physical and mechanical properties from previous studies used as the basis in this study (Wardhana et al, 2015)

Purun Tikus that is used in this study as particles with the material composition (factor A) is given reinforcement shape (factor B). Factor A (materials composition), consists three levels of factors: A1 $=50 \mathrm{~g}$ Purun Tikus+ $575 \mathrm{~g}$ PPC, $\mathrm{A} 2=75 \mathrm{~g}$ Purun Tikus $+550 \mathrm{~g}$ PPC, $\mathrm{A} 3=100 \mathrm{~g}$ Purun Tikus+ $525 \mathrm{~g}$ PPC and factor $\mathrm{B}$ (form reinforcement), consists: $\mathrm{B} 1=$ without reinforcement and $\mathrm{B} 2=$ parallel reinforcement.

\section{Results And Discussions}

Based on the treatments given, it obtained water content, density, thickness swelling, MoE and MoR as follows:

Table 1. Water Content Test Results (\%) Cement Board Particles

\begin{tabular}{|l|l|l|l|l|l|}
\hline Factor B & \multirow{4}{4}{ Factor $\mathbf{A}$} & SNI 03-2104-1991 \\
\cline { 3 - 5 } & Repetition & $\mathbf{A 1}$ & $\mathbf{A 2}$ & $\mathbf{A 3}$ & \\
\hline \multirow{4}{*}{ B1 } & 1 & 3,35 & 4,96 & 5,40 & \\
\cline { 2 - 5 } & 2 & 4,27 & 5,31 & 6,38 & \\
\cline { 2 - 5 } & 3 & 3,95 & 5,12 & 5,89 & \\
\cline { 2 - 5 } & Total & 11,57 & 15,39 & 17,67 & \\
\cline { 2 - 5 } & Average & $\mathbf{3 , 8 6}$ & $\mathbf{5 , 1 3}$ & $\mathbf{5 , 8 9}$ & Maximum 14\% \\
\hline \multirow{4}{*}{ B2 } & 1 & 4,70 & 5,59 & 6,77 & \\
\cline { 2 - 5 } & 2 & 5,59 & 6,90 & 7,41 & \\
\cline { 2 - 5 } & 3 & 5,54 & 6,75 & 7,17 & \\
\cline { 2 - 5 } & Total & 15,83 & 19,24 & 21,35 & \\
\cline { 2 - 5 } & Average & $\mathbf{5 , 2 8}$ & $\mathbf{6 , 4 1}$ & $\mathbf{7 , 1 2}$ & Maximum 14\% \\
\hline
\end{tabular}

All the test materials have met the SNI 03-2104-1991 requirement of water content, which is at maximum of $14 \%$. The lowest water content is the A1B1 test $(3.86 \%)$, which is Purun Tikus particle $50 \mathrm{~g}+$ PPC $575 \mathrm{~g}$ without reinforcement and the highest is in the A3B2 test (7.12\%), which is Purun Tikus particle 100 $\mathrm{g}+$ PPC $525 \mathrm{~g}$ with parallel reinforcement.

Based on statistical analysis, three cement board material composition of Purun Tikus give a significant effect on water content.

Based on Duncan analysis, the composition of Purun Tikus particle $50 \mathrm{~g}+$ PPC $575 \mathrm{~g}$ is significantly different from the composition of Purun Tikus particle $75 \mathrm{~g}+$ PPC $550 \mathrm{~g}$ toward water content, it also significantly different from composition of Purun Tikus particle $100 \mathrm{~g}+$ PPC $525 \mathrm{~g}$.

Table 2. Density Test Results $\left(\mathrm{kg} / \mathrm{cm}^{3}\right)$ Cement Board Particle

\begin{tabular}{|l|l|l|l|l|l|}
\hline Factor B & Repetition & Factor A & A2 & A3 & \\
\cline { 2 - 5 } & & A1 & 03-2104-1991 \\
\hline \multirow{5}{*}{ B1 } & 1 & 0,83 & 0,93 & 0,75 & \\
\cline { 2 - 6 } & 2 & 0,82 & 0,94 & 0,84 & \\
\cline { 2 - 6 } & 3 & 0,82 & 0,91 & 0,81 & \\
\cline { 2 - 6 } & Total & 2,47 & 2,78 & 2,40 & \\
\cline { 2 - 6 } & Average & 0,82 & 0,93 & 0,80 & Minimum 0,57 \\
\hline \multirow{5}{*}{ B2 } & 1 & 0,74 & 0,72 & 0,72 & \\
\cline { 2 - 6 } & 2 & 0,90 & 0,83 & 0,88 & \\
\cline { 2 - 6 } & 3 & 0,81 & 0,79 & 0,76 & \\
\cline { 2 - 5 } & Jumlah & 2,45 & 2,34 & 2,36 & \\
\cline { 2 - 5 } & Rerata & 0,82 & 0,78 & 0,79 & Minimum 0,57 \\
\hline
\end{tabular}

All the test materials have met the requirement SNI 03-2104-1991 of density, which is at minimum of $0.57 \mathrm{~g} / \mathrm{cm}^{3}$. The lowest density in A2B2 test $\left(0.78 \mathrm{~g} / \mathrm{cm}^{3}\right)$ which is Purun Tikus particle $75 \mathrm{~g}+$ PPC $550 \mathrm{~g}$ with parallel reinforcement and the highest is in the A2B1 test $\left(0.93 \mathrm{~g} / \mathrm{cm}^{3}\right)$ which is Purun Tikus particle $75 \mathrm{~g}$ + PPC $550 \mathrm{~g}$ without reinforcement. 

the density.

Based on statistical analysis, three material composition of Purun Tikus give no significant effect on

Based on Duncan analysis, the composition of Purun Tikus particle $50 \mathrm{~g}+$ PPC $575 \mathrm{~g}$ is not significantly different from Purun Tikus particle $100 \mathrm{~g}+$ PPC $525 \mathrm{~g}$ toward density, it also not significantly different from the composition of Purun Tikus $75 \mathrm{~g}+$ PPC $550 \mathrm{~g}$.

Table 3. Thickness Swelling Test Results (\%) Cement Board Particle

\begin{tabular}{|l|l|l|l|l|l|}
\hline Factor B & \multirow{3}{*}{ Repetition } & Factor A & SNI 03-2104-1991 \\
\cline { 2 - 5 } & 1 & 0,91 & $\mathbf{A 2}$ & $\mathbf{A 3}$ & \\
\hline \multirow{4}{*}{ B1 } & 2 & 0,95 & 1,00 & 0,43 & \\
\cline { 2 - 6 } & 3 & 0,89 & 0,87 & 0,46 & \\
\cline { 2 - 6 } & Total & 2,75 & 2,30 & 1,31 & \\
\cline { 2 - 6 } & Average & $\mathbf{0 , 9 2}$ & $\mathbf{0 , 7 7}$ & $\mathbf{0 , 4 4}$ & Maximum 12\% \\
\hline \multirow{4}{*}{ B2 } & 1 & 1,34 & 0,43 & 1,64 & \\
\cline { 2 - 6 } & 2 & 0,43 & 0,43 & 1,69 & \\
\cline { 2 - 6 } & 3 & 0,98 & 0,51 & 1,64 & \\
\cline { 2 - 6 } & Total & 2,75 & 1,37 & 4,97 & \\
\cline { 2 - 6 } & Average & $\mathbf{0 , 9 2}$ & $\mathbf{0 , 4 6}$ & $\mathbf{1 , 6 6}$ & Maximum 12\% \\
\hline
\end{tabular}

All test materials have met the SNI 03-2104-1991 requirement of thickness swelling, which is maximum of $12 \%$. The lowest thickness swelling value is in the A3B1 test $(0.44 \%)$, which is Purun Tikus particle $100 \mathrm{~g}+$ PPC $525 \mathrm{~g}$ without reinforcement and the highest is in the A3B2 test (1.66\%), which is Purun Tikus particle $100 \mathrm{~g}+$ PPC $525 \mathrm{~g}$ parallel reinforcement.

Based on statistical analysis, three material composition of Purun Tikus give a significant influence on the thickness swelling.

Based on Duncan analysis, composition of Purun Tikus particle $75 \mathrm{~g}+$ PPC $550 \mathrm{~g}$ is significantly different from the composition of Purun Tikus particle $50 \mathrm{~g}+$ PPC $575 \mathrm{~g}$ and it is significant different from composition of Purun Tikus particle $100 \mathrm{~g}+$ PPC $525 \mathrm{~g}$ toward thickness swelling.

Table 4. MoE Test Results $\left(\mathrm{kg} / \mathrm{cm}^{2}\right)$ Cement Board Particle

\begin{tabular}{|c|c|c|c|c|c|}
\hline \multirow[t]{2}{*}{ Factor B } & \multirow[b]{2}{*}{ Repetition } & \multicolumn{3}{|l|}{ Factor $\mathbf{A}$} & \multirow[t]{2}{*}{ SNI 03-2104-1991 } \\
\hline & & A1 & A2 & A3 & \\
\hline \multirow[t]{5}{*}{ B1 } & 1 & - & 7861,20 & - & \\
\hline & 2 & - & 4345,09 & 3608,45 & \\
\hline & 3 & - & - & 5005,67 & \\
\hline & Total & - & 12206,29 & 8614,12 & \\
\hline & Average & - & 6103,14 & 4307,06 & \\
\hline \multirow[t]{5}{*}{ B2 } & 1 & - & 5889,03 & - & \\
\hline & 2 & 6074,83 & 5619,71 & 5954,54 & \\
\hline & 3 & 5476,78 & - & - & \\
\hline & Total & 11551,61 & 11508,74 & 5954,54 & \\
\hline & Average & 5770,80 & 5754,37 & 5954,54 & \\
\hline
\end{tabular}

All test materials have met the SNI 03-2104-1996 requirement of MoE, which is maximum of 15,000 $\left(\mathrm{kg} / \mathrm{cm}^{2}\right)$. The lowest MoE value is in the A3B1 test $\left(4307.06 \mathrm{~kg} / \mathrm{cm}^{2}\right)$, which is Purun Tikus particle $100 \mathrm{~g}+$ PPC $525 \mathrm{~g}$ without reinforcement and the highest is in the A2B1 test $\left(6103.14 \mathrm{~kg} / \mathrm{cm}^{2}\right)$, which is Purun Tikus particle $75 \mathrm{~g}+$ PPC $550 \mathrm{~g}$ without reinforcement. Based on statistical analysis, three material composition of Purun Tikus give no significant effect on MoE.

Based on Duncan analysis, Each composition was significantly different, which means the composition of Purun Tikus particle $50 \mathrm{~g}+$ PPC $575 \mathrm{~g}$, composition of Purun Tikus particle $100 \mathrm{~g}+$ PPC $525 \mathrm{~g}$, composition of Purun Tikus particle $75 \mathrm{~g}+$ PPC 550 obtained different MoE value.

The material composition of Purun Tikus particle $75 \mathrm{~g}+$ PPC $550 \mathrm{~g}$ will be selected, because it has the highest MoE value.

Table 5. MoR Test Results $\left(\mathrm{kg} / \mathrm{cm}^{2}\right)$ Cement Board Particle

\begin{tabular}{|l|l|l|l|l|l|}
\hline Factor B & \multirow{2}{*}{ Repetition } & \multicolumn{3}{|l|}{ Factor A } & SNI 03-2104-1991 \\
\cline { 3 - 5 } & 1 & 7,08 & $\mathbf{A}$ & $\mathbf{A}$ & \\
\hline \multirow{3}{*}{ B1 } & 2 & 6,35 & 6,43 & 6,35 & \\
& 3 & 6,77 & 13,63 & 9,53 & \\
\cline { 2 - 5 } & 3 & 8,94 & \\
\hline
\end{tabular}




\begin{tabular}{|l|l|l|l|l|l|}
\hline \multirow{4}{*}{ B2 } & Total & $\mathbf{2 0 , 2 0}$ & 37,37 & $\mathbf{2 4 , 8 2}$ & \\
\cline { 2 - 6 } & Average & $\mathbf{6 , 7 3}$ & $\mathbf{1 2 , 4 6}$ & $\mathbf{8 , 2 7}$ & Minimum 17 \\
\cline { 2 - 6 } & 1 & 6,35 & 8,92 & 5,38 & \\
\cline { 2 - 6 } & 2 & 12,83 & 21,50 & 12,57 & \\
\cline { 2 - 6 } & 3 & 14,77 & 18,90 & 19,83 & \\
\cline { 2 - 6 } & Total & 33,95 & 49,32 & 37,78 & \\
\cline { 2 - 6 } & Average & $\mathbf{1 1 , 3 2}$ & $\mathbf{1 6 , 4 4}$ & $\mathbf{1 2 , 5 9}$ & Minimum 17 \\
\hline
\end{tabular}

Not all material tests meet the SNI 03-2104-1996 requirement of MoR, which is minimum $17 \mathrm{~kg} / \mathrm{cm}^{2}$. The lowest MoR value is in the A1B1 test $\left(6.73 \mathrm{~kg} / \mathrm{cm}^{2}\right)$, which is Purun Tikus particle $50 \mathrm{~g}+$ PPC $575 \mathrm{~g}$ without reinforcement and the highest is in the A2B2 test $\left(16.44 \mathrm{~kg} / \mathrm{cm}^{2}\right)$, which is Purun Tikus particle $75 \mathrm{~g}$ + PPC $550 \mathrm{~g}$ with parallel reinforcement. Based on statistical analysis, three material composition of Purun Tikus give no significant effect on MoR.

Based on Duncan analysis, composition of Purun Tikus particle $50 \mathrm{~g}+$ PPC $575 \mathrm{~g}$ and composition of Purun Tikus particle $75 \mathrm{~g}+$ PPC $550 \mathrm{~g}$ and composition of Purun Tikus particle $100 \mathrm{~g}+$ PPC $525 \mathrm{~g}$ are not significantly different toward MoR.

Because the MoR value is significantly affecting the quality of the cement board, therefore the Ducan test value can be used as a basic to continue to the next research. If we look at the Duncan test on materials combination factor, because of each factor level is not significantly different, therefore for the next studies should be made a significant difference between the composition of Purun Tikus particle and try to another material form, for example, added with fibers form.

\section{Conclusion}

All Purun Tikus particle with a composition of $50 \mathrm{~g}+$ PPC $575 \mathrm{~g}, 75 \mathrm{~g}+$ PPC $550 \mathrm{~g}$ and $100 \mathrm{~g}+$ PPC $525 \mathrm{~g}$ has met the requirements of SNI 03-2104-1991 on water content, density, thickness swelling, MoE. Not all the Purun Tikus particle meets the MoR in SNI 03-2104-1996 requirement.

The lowest water level in the composition is at $50 \mathrm{~g}$ Purun Tikus particle without reinforcement, while the highest at $100 \mathrm{~g}$ Purun Tikus particle with parallel reinforcement. The lowest density in the composition is at $75 \mathrm{~g}$ Purun Tikus particle with parallel reinforcement while the highest at $75 \mathrm{~g}$ Purun Tikus particle without reinforcement.

The lowest thickness swelling in the composition of $100 \mathrm{~g}$ Purun Tikus particle without reinforcement, while the highest at $100 \mathrm{~g}$ Purun Tikus particle with parallel reinforcement. The lowest MoE in the composition of $100 \mathrm{~g}$ Purun Tikus particle without reinforcement, while the highest in $75 \mathrm{~g}$ Purun Tikus particle without reinforcement. The lowest MoR in the composition of $50 \mathrm{~g}$ Purun Tikus without reinforcement, while the highest in $75 \mathrm{~g}$ Purun Tikus particle with parallel reinforcement.

The composition of Purun Tikus particle $75 \mathrm{~g}+$ PPC $550 \mathrm{~g}$ will be selected, because it has the highest value of the MoE.

The composition of Purun Tikus particle $(50 \mathrm{~g}, 75 \mathrm{~g}, 100 \mathrm{~g})$ have a significant effect on the water content and the thickness swelling. The composition of Purun Tikus particle $(50 \mathrm{~g}, 75 \mathrm{~g}, 100 \mathrm{~g})$ have no significant effect on the density, the MoE and the MoR.

\section{References}

[1] Jumberi, A., M.Sarwani dan Koesrini. 2004. Komponen Teknologi Pengelolaan Lahan dan Tanaman Untuk Meningkatkan Produktivitas dan Efisiensi Produksi di Lahan Sulfat Masam dalam Alihamsyah, T dan Izzuddin, N. Laporan Tahunan Penelitian Pertanian Lahan Rawa Tahun 2003. Balai Penelitian Pertanian Lahan rawa. Banjarbaru. hal 9-14.

[2] Maloney, T.M. 1977. Modern Particleboard \& Dry-Process Fibreboard Manufacturing. Miller Freeman Publication, San Francisco, California

[3] Noor, M. 2004. Lahan Rawa Sifat dan Pengelolaan Tanah Bermasalah Sulfat Masam. PT Raja Grafindo Persada. Jakarta

[4] Rahadi, 2007., Penelitian Penyebaran jenis tumbuhan purun Barito Kuala Kalsel Steenis, C. G. G. J, Van. 2006. Flora. PT Pradnya Paramita. Jakarta.

[5] Suhasman. 2012. Perbandingan Karakteristik Papan Semen Dari Batang dan Cabang Kayu Asal Hutan Rakyat. Jurnal Perennial. Vol8, No 1:30-35, ISSN :1412-7784.

[6] Wang, B., Panigrahi, S., Tabil, L., Crerar, W.J., Powell, T., Kolybaba, M., and Sokhansanj, S. 2003. Flax Fiber-Reinforced Thermoplastic Composites. Journal The Society for Eng. In Agricultural, Food, and Biological Systems, Dep. Of Agricultural and Bioresource Eng. Univ. of Saskatchwan., Canada.

[7] Wardhana,H.,Soemarno,Rachmansyah, A, Fathurrazie, 2015. Chemical, Physical, and Mechanical Features of Purun Tikus (Eleocharis dulcis) Fiber. Jurnal AARJMD ISSN 2319-2801, Vol 2. Issue. 3 August 2015, pp 127-134. 